\title{
Information Potential and Threats of the Internet in the Views of High School Students and Their Teachers (Based on Applied Sociological Research)
}

\author{
Shalagina E.V.
}

\author{
Ural State Pedagogical University, Yekaterinburg, Russian Federation \\ Email: elshal96@gmail.com
}

\begin{abstract}
Increasingly, the wide spread of the Internet determines the specifics of the social situation of a modern metropolis. The two leading educational subjects (teachers and schoolchildren) are also active users of the Internet. Information, technological, communication and educational resources, various risks and threats enter their lives in general, and their educational space in particular, together with the use of the Internet. Analysis of the degree of trust (distrust) in online information, recognition of potential dangers, determination of mechanisms of personal and group protection and skills of their application - these are the range of issues that require special applied research in the current circumstances, especially relevant in the modern educational space. Using the example of an original sociological study, the author shows the emerging trends characteristic of the Ural region in this problem field, and draws conclusions about the features of the views of high school students and their teachers - residents of a large Ural megalopolis - about the information potential, demanded resources and possible threats caused by the Internet. The author pays special attention to the description of the social phenomenon of cyberbullying. The results obtained in the course of the survey methods are used to determine the level of awareness of students and teachers about this kind of phenomenon, as well as to describe their personal experience of encountering situations of bullying in the online environment.
\end{abstract}

Keywords: Internet space, social networking, online education, cyberbullying

\section{INTRODUCTION}

The Internet is now widely included in the life of a modern metropolis. And Internet research (InternetStudies) for science is increasingly becoming an interdisciplinary and multidisciplinary field of fundamental and applied research.

The Internet technologies and infrastructure, practices and contexts of its use among various groups of the population, and legal regulation of these processes are traditionally identified as the object of such research.

Sociological interest in this problem is represented by a positivist, interpretive and critical paradigm, as noted by Rykov Yu. G. [6, p. 370]. In his opinion, the positivist approach involves the use of quantitative methods of collecting initial social information and raises questions: who is online, how much time is spent, what actions are performed in this space. Qualitative methodology is used within the framework of an interpretive approach and solves the questions: why people use the Internet, what importance they attach to it, how it affects their life. A critical approach to studying the Internet is used to raise regulatory questions: whether the Internet today expands people's freedoms and opportunities or contributes to their oppression, leads to the smoothing of social inequality or its intensification.

In this regard, it should be emphasized that the thematic repertoire of Internet research and research of the Internet is currently extremely wide, as shown by reviews of numerous secondary sociological data. Today, they contain a variety of information: from studying the trust of Russians in information obtained from Internet sources [1], to the attitude to the so-called fake news [2], and determining the characteristics of the audience of various Internet resources, such as the video hosting YouTube [3]. How important is the Internet in the lives of high school students and their teachers? We will try to answer this question using the results of sociological research on the theme "Multivariate study of conflicts in micro and macro environment of adolescents as a way of determining the strategy of prevention of extremist manifestations", which was conducted in educational institutions of Yekaterinburg in October and December 2018 on request of the Department of education of the Administration of Yekaterinburg by sociologists of Ural State Pedagogical University. 


\section{MATERIAL AND METHODS}

In total, 1,500 eighth-graders and 300 teachers of educational organizations in Yekaterinburg took part in the survey. To collect initial social information, the method of formalized face-to-face handout questionnaires was used. One of the tasks was to determine the level of trust and assess the security of the Internet space with which today's teenagers - residents of a modern metropolis, and their teachers interact.

As a result of the analysis of the data obtained, it can be concluded that the prevailing majority of school children surveyed (98\%), today, indeed, regularly use Internet services, which confirms the conclusions of all-Russian surveys.

\section{Do you use the Internet?}

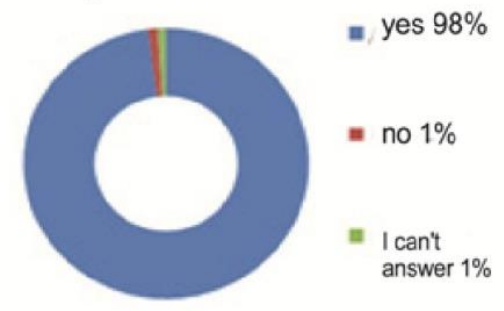

Figure 1 The use of the Internet (high school students)

We found the same proportions when analyzing the teachers' responses. $98 \%$ of the teachers regularly use the Internet. And only a small part of the respondents (1\%) do not use its services.

Taking into account the availability and prevalence of the network in the metropolis, it is necessary to understand the goals that consumers of these services pursue. According to our respondents, their goals can be divided into informational, educational, communication, gaming, etc.

\section{RESULTS AND DISCUSSION}

Priorities in the designation of a target when using the Internet for high school students are as follows.

Thus, the leading activity of older adolescents, which is communication, today has moved from direct social interaction into the area of online communities and the Internet space, and thus acquired distinctive features and new peculiarities including: special rules for this kind of communication, language, symbols, regulations, and formats, possibilities and limitations. In addition, it is obvious that the Internet has firmly established itself as an active partner of the school in its information and educational opportunities. And also, the "network" today can "compete" with TV and radio for an audience in the field of broadcasting news information.

Distance education is perceived by school-age respondents as additional online classes and self-education in various subject areas that they can receive via the Internet. The areas of distance education that they highlighted in the survey relate to the study of foreign languages (English, Czech, Japanese were mentioned in the questionnaires) and various sciences (the students indicated, first of all, natural science and technical science cycles: chemistry, biology, mathematics, computer science).

Table 1 Internet usage purposes (high school students)

\begin{tabular}{|c|c|c|}
\hline rating & purpose & $\begin{array}{c}\text { \% of high school } \\
\text { students } \\
\text { surveyed }\end{array}$ \\
\hline 1 & Social media communication & $83 \%$ \\
\hline 2 & $\begin{array}{c}\text { Preparing materials for school } \\
\text { classes }\end{array}$ & $65 \%$ \\
\hline 3 & $\begin{array}{c}\text { Downloading movies and } \\
\text { music }\end{array}$ & $42 \%$ \\
\hline 4 & $\begin{array}{c}\text { Search and getting to know } \\
\text { the news }\end{array}$ & $33 \%$ \\
\hline 5 & $\begin{array}{c}\text { Network computer games } \\
\text { Getting distance education }\end{array}$ & $5 \%$ \\
\hline 7 & $\begin{array}{c}\text { Rehearsal of exams and test } \\
\text { works on simulators of } \\
\text { special sites (FIPI, "Reshu } \\
\text { YeGE", etc.) }\end{array}$ & $18 \%$ \\
\hline
\end{tabular}

In addition to the above mentioned purposes and guidelines for using Internet resources, high school students named a number of other reasons for addressing to them. Among the most common responses were such as reading fiction, watching movies, listening to music, solving tasks of distance competitions in academic subjects, communicating with friends and relatives via social networks and video, searching for additional educational materials through webinars, using electronic diaries in the educational process, and computer games. Let's look at the results of a survey of teachers, suggesting that their purposes for using the "world wide web" may have other directions.

Table 2 Purposes of the use of the Internet (teachers)

\begin{tabular}{|c|c|c|}
\hline rating & purpose & $\begin{array}{c}\text { \% of teachers } \\
\text { surveyed }\end{array}$ \\
\hline 1 & $\begin{array}{c}\text { Preparing materials for school } \\
\text { classes }\end{array}$ & $91 \%$ \\
\hline 2 & Reading news & $54 \%$ \\
\hline 3 & Social media communication & $43 \%$ \\
\hline 4 & Reading scientific literature & $33 \%$ \\
\hline 5 & $\begin{array}{c}\text { Downloading movies and } \\
\text { music }\end{array}$ & $29 \%$ \\
\hline 6 & Getting distance education & $26 \%$ \\
\hline 7 & Network computer games & $2 \%$ \\
\hline
\end{tabular}


Thus, the Internet in the life and work of a teacher is, in contrast to the adolescent and youth audience, primarily an information and educational resource. In second place, relative to this category of respondents, its communication capabilities fall (so the teachers note that they communicate with parents and students through electronic diaries, give out and check educational tasks, organize interaction between family and school).

Let's turn to a more detailed description of the position "getting distance education", since every fourth teacher interviewed chooses this form and purpose of using the Internet. We identified the features of distance learning that interest the respondents mostly, which was revealed in the survey of teachers. They are attracted by the opportunity to study at foreign language courses, advanced training and retraining programs in various fields (including innovative educational technologies, programming, speech pathology education, etc.), to use video lessons on educational subjects to prepare additional material for them, solve Unified State exam tasks, participate in online competitions in professional skills.

In addition to the above mentioned purposes, teachers use the Internet to solve other tasks that are not related to their professional activities. The most common reasons for applying are money transactions in an online bank, access to the portal of "public services", utilities payment and other payments, purchase of plane tickets and railway tickets online, and other opportunities to make online purchases. In addition, teachers read books and magazines online, listen to music, and communicate.

Emphasizing the crucial role of the Internet in the life of modern urban teenagers, it is necessary to determine how much it influences the formation of their personal opinions, attitudes and assessments of various social phenomena and processes. Finding this out is possible not only by analyzing the frequency of access to Internet resources, identifying the specifics of the tasks solved with their help, but also by studying the concept of "trust". We tried to find out how much high school students and teachers trust the information they receive through social networks and other Internet resources. The positions of our respondents were not evenly distributed. They are shown in the following chart.

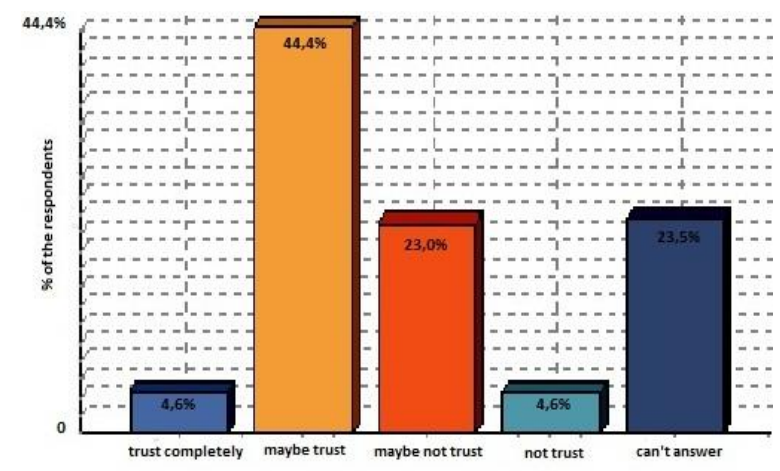

Figure 2 Trust in the information from the Internet (high school students)
Table 3 How much do you trust the information that comes to you through the Internet and social networks? (schoolchildren)

\begin{tabular}{|c|c|c|}
\hline № & answers & \%of respondents \\
\hline 1 & I trust completely & 4.5 \\
\hline 2 & Maybe, I trust & 44.2 \\
\hline 3 & Maybe, I don't trust & 22.9 \\
\hline 4 & I don't trust & 4,5 \\
\hline 5 & I can't answer & 23,4 \\
\hline
\end{tabular}

Thus, in general, every second respondent has a high degree of trust in the information that becomes available through social networks. However, it is necessary to conclude that modern high school students do not show absolute readiness to unconditionally believe and unconditionally trust social networks, but are inclined to check and question information that comes to them through the Internet.

The opinions of the teachers in this regard are sharply polarized: only $2 \%$ of the surveyed teachers fully trust the information from the network; in general, $4 \%$ of the respondents prefer not to trust it. The majority of the surveyed teachers ( $82 \%$ of the respondents) note the fact that they often work online only with the verified resources and tend to trust the information flow generated only by these sites.

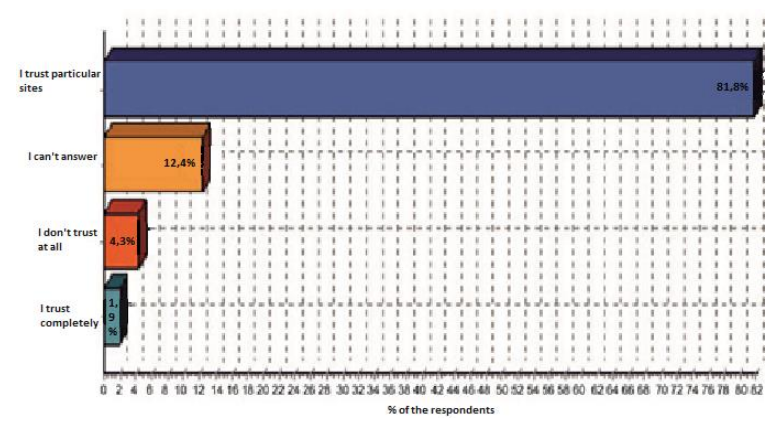

Figure 3 Trust in the information from the Internet (teachers)

Table 4 How much do you trust the information that comes to you through the Internet and social networks? (teachers)

\begin{tabular}{|c|l|c|}
\hline № & \multicolumn{1}{|c|}{ answers } & \%of respondents \\
\hline 1 & I trust completely & 2 \\
\hline 2 & $\begin{array}{l}\text { I trust only verified } \\
\text { resources (sites, etc.) }\end{array}$ & 44,2 \\
\hline 3 & I don't trust at all & 4 \\
\hline 4 & I can't answer & 12 \\
\hline
\end{tabular}

Along with an innovative resource that implies the possibilities of the Internet, threats have also come into today's life. Through communication and information 
materials, they search for potential "readers" of "death groups", terrorist organizations, financial fraudsters, etc. The modern social situation, which also determines the educational space, forms new forms of aggressive behavioral manifestations. In this regard, we should note the emergence of such phenomena as cyberbullying, online grooming (network grooming) etc.

Cyberbullying is a social phenomenon that is a type of aggressive behavior [10]. This phenomenon can be described as a system of deliberate insults, threats, and messages of dirt information carried out using modern means of communication. As a rule, these actions are usually performed over a certain period of time.

In the scientific literature of recent years, the term "bullying" has been used to describe behavior that is characterized by a deliberate, persistent and active desire to cause harm in situations of organized social interaction [11].

Bullying is the aggression of some children against others, when there is an inequality of forces, when the victim appears. Bullying is not always expressed in a physical attack. Most often, in practice, there are psychological forms of bullying:

- verbal harassment (insults, malicious and obscene jokes, taunts, etc.);

- spreading rumors and gossip;

- boycott, deliberate isolation.

Thus, cyberbullying should be understood as an activity based on the organization of bullying, which is a systematic, repeated bullying, insult, humiliation of the dignity of another person, which is implemented through the Internet or using modern means of communication. Typical actions carried out in this kind of bullying include the dissemination of deliberately false information (rumors and gossip) about a person, ridicule and provocation, direct insults and intimidation, the organization of social isolation (boycott and demonstrative disregard), attacks that infringe on the honor and dignity of a person.

Modern cyberbullying has a number of features [12]:

1) round-the-clock interference in personal life;

2) bullying has no time or geographical restrictions;

3) long-term exposure;

4) permanent access through technical means to the victim: in this case, the mobile phone acts as a tool, and the personal profile in social networks and email - as a channel;

5) unlimited audience for impact;

6) high speed of information dissemination;

7) technical difficulties for neutralizing (or blocking) content directed against the "victim";

8 ) the anonymity of the stalker.

As the results of all-Russian sociological surveys show, today an increasing number of schoolchildren are familiar with this phenomenon.

We also looked at it in a survey of high school students to identify our respondents' perceptions of this social phenomenon, as well as to describe their personal experiences, if any.

Table 5 Have you encountered such a phenomenon as cyberbullying (high school students)?

\begin{tabular}{|c|l|c|}
\hline № & \multicolumn{1}{|c|}{ answers } & $\begin{array}{c}\text { \% of } \\
\text { respondents }\end{array}$ \\
\hline 1 & I've been told about it & 41,6 \\
\hline 2 & No, this is the first I've heard of it & 33,5 \\
\hline 3 & $\begin{array}{l}\text { Yes, I have such personal } \\
\text { experience }\end{array}$ & 15,4 \\
\hline 4 & $\begin{array}{l}\text { One of my friends suffered from } \\
\text { cyberbullying }\end{array}$ & 7,1 \\
\hline 5 & $\begin{array}{l}\text { One of my friends was the initiator } \\
\text { of cyberbullying }\end{array}$ & 3,9 \\
\hline
\end{tabular}

According to the results of the survey, the majority of high school students we surveyed are familiar with this phenomenon: $42 \%$ of the students said that they were told about it.

At the same time, about a third of respondents heard about the concept of "cyberbullying" for the first time during the study $-34 \%$ of the respondents defined their experience in this issue as such.

At the same time, $15 \%$ of the respondents have personal experience of bullying in the Internet space. $7 \%$ of the respondents indicated that someone from their immediate environment (friends) was affected by cyberbullying. And $4 \%$ of the schoolchildren admitted that they have initiators of such "cyberactivity" among their friends.

Thus, every fourth high school student interviewed directly or indirectly has faced organized and systemic aggression through modern means of communication and online, which cannot but cause alarm.

Comparing the results of the survey of teachers with the results of the survey of schoolchildren, it should be emphasized that the following tendencies are observed:

- personal experience of teachers in the field of cyberbullying ("encountered personally") is much less than that of the children: only $2 \%$ of the teachers noted it; - at the same time, $5 \%$ of the teachers surveyed indicate the presence of examples from personal experience in the immediate environment: "one of my friends, acquaintances, and colleagues suffered from cyberbullying".

- among the teachers, there is also a group that has never heard of this phenomenon, and the proportion of its presence in the total mass of the respondents is identical to that found in the responses of the schoolchildren: $32 \%$ of the teachers indicated that "they have never heard of it";

- this problem occurs in the process of communication between teachers and colleagues and students more often than in the discussion of teenagers among themselves: 52 $\%$ of the teachers say that they were told about cyberbullying by colleagues, $12 \%$ of the teachers heard about it from their students. 


\section{CONCLUSION}

1. The prevailing majority of school children surveyed ( 98 $\%)$ regularly use Internet services. The goals that consumers of these services pursue can be divided into information, educational, communication, and gaming.

2. The leading activity of older teens, which is communication, moved today from direct interaction into the area of online communities and the Internet space, it has acquired the characteristics and new features (special rules of communication, language and symbols used, regulations and formats, possibilities and limitations). The Internet has established itself as an active partner of the school in its information and educational opportunities. The network today can "compete" with TV and radio for an audience in the field of news information. Distance education is perceived by school-age respondents as additional online classes and self-education in various subject areas.

3. With a high degree of certainty every second of the respondents refers to the information that is made available through social networks.

About a third of school children belong to a group that do not trust information obtained in this way. We can conclude that modern high school students do not show an unconditional willingness to trust Internet resources, they are more likely to question the information that comes to them over the Internet, and check it.

4. Every fourth high school student interviewed directly or indirectly has experienced organized and systemic aggression (cyberbullying) through modern means of communication and online.

5. Personal experience of teachers associated with the phenomenon of cyberbullying is significantly less than that of their high school students, however, 5\% of the teachers surveyed indicate the presence of cases related to it in their immediate environment ("one of my friends, acquaintances, colleagues suffered from cyberbullying"). This issue is now increasingly emerging in the process of communication between teachers and colleagues and students. In this connection, there is a question that requires the continuation of such research practices, which can be formulated in this way: "How well are current high school students prepared for the possible dangers and potential risks contained in the Internet, and how are their teachers able to prepare them for this today?".

\section{REFERENCES}

[1] Analytical report of February 4, 2020 by AllRussian center of public opinion research [Analiticheskiy otchet VTsIOM ot 4 fevralya 2020], VTSIOM, available

at:
Russian).

[2] Analytical report of March 20, 2019 by All-Russian center of public opinion research [Analiticheskiy otchet VTsIOM ot 20 marta 2019] VTSIOM, available at: https://wciom.ru/index.php?id=236\&uid=9603(inRussi an).

[3] Analytical report of November 25, 2019 by AllRussian center of public opinion research [Analiticheskiy otchet VTsIOM ot 25 noyabrya 2019], VTSIOM, available at: https://wciom.ru/index.php?id=236\&uid=10022inRussi an).

[4] Voronkin, A. S. (2014), "Social networks: evolution, structure, analysis" ["Sotsialniye seti: evolyutsiya, struktura, analiz"], Obrazovatelniye tehnologii i obschestvo, V. 17, No. 1, pp. 650-675.

[5] Doktorov, B. (2000), "Online surveys: the routine of the coming century" ["Onlaynoviye oprosy: Obydennost' nastupivshego stoletiya"], Teleskop, No. 4, pp. 16-31.

[6] Rykov, Yu. G., Nagorny, O. (2017), “The field of Internet research in social sciences" ["Oblast' internetissledovaniy v sotsialnyh naukah"], Sotsiologicheskoye obozreniye, V. 16, No. 3, pp. 366-394.

[7] Russians and the Internet: all-Russian research, July 2000 [Rossiyane i Internet: Vserossiyskoye issledovaniye], Tsentr ROMIR, available at: http://www.romir.ru/market/internet/07_2000/internet. htm(inRussian).

[8] Filippova, T. V. (1999), "Using the Internet for sociological research", Internet and modern society: Theses of the second all-Russian scientific and methodological conference November 29 - December 3, 1999 ["Ispolzovaniye Internet dlya sotsiologicheskih issledovaniy", Internet i sovremennoye obschestvo: Tezisy vtoroy Vserossiyskoy nauchno-metodicheskoy konferentsii:], St. Petersburg, pp. 41-42.

[9] DiMaggio, P., Hargittai, E., Neuman W. Rassel, Robinson J.P. (2001), "Social Implications of the Internet", Annual Review of Sociology, Vol. 27, pp. 307-336, available

at: https://doi.org/10.1146/annurev.soc.27.1.307.

[10] Hester, Wesley P. (2012), Cyberbullying intervention: A case study analysis of stakeholder perceptions regarding the authority of school administrators in addressing cyberbullying issues. 
[12] Smith, P. K., Mahdavi, J., Carvalho, M., Fisher, S., Russel, S., \&Tippett, N. (2008), "Cyber bullying: Its nature and impact in secondary school pupils", Journal of Child and Psychiatry, V. 49, pp. 376-385.

[11] Olweus, D. (1993), Bullying at school. What we know and what we can do, Oxford : Blackwell, $135 \mathrm{p}$. 